\title{
Intra-annual radial growth of European beech - a case study in north easternmost stand in Europe
}

\author{
Oskars Krišāns ${ }^{1}$, Līga Puringa ${ }^{1}$, Dāvis Mesters ${ }^{2}$, Rolands \\ Kāpostinsš ${ }^{1}$, Juris Rieksts-Riekstingšs ${ }^{1}$ and Âris Jansons ${ }^{1, *}$
}

Krišāns, O., Puriņa, L., Mesters, D., Kāpostiņš, R., Rieksts-Riekstiņš, J., Jansons, Ā. 2016. Intra-annual radial growth of European beech - a case study in north easternmost stand in Europe. - Forestry Studies | Metsanduslikud Uurimused 65, 34-42. ISSN 14069954. Journal homepage: http://mi.emu.ee/forestry.studies

\begin{abstract}
Fagus sylvatica L. is one of the most important commercial tree species in Europe and its natural distribution range is expected to shift northwards due to climatic changes. Detailed information of factors affecting its growth is crucial as a basis for recommendations of wider use of this tree species. Aim of the study was to characterize the changes of radial growth intensity of European beech during a vegetation season. In mature beech stand in northwest Latvia two sample trees (dominant (DT) and suppressed (ST)) were selected in Hylocomiosa forest type. Continuous measurements of changes of stem diameter and xylem sap flow as well as meteorological parameters were carried out. Stem cycle approach was applied to distinguish the duration of contraction, expansion and increment of the stem. Onset and cessation of growth of the ST tree was observed several days later compared with DT and mean growth intensity during the entire observation period was considerably lower $\left(0.014 \mathrm{~mm} /\right.$ day $^{-1}$ for ST and $0.022 \mathrm{~mm} /$ day $^{-1}$ for DT, respectively). Most intensive growth increment diurnally was observed in the early morning before sunrise, and seasonally till beginning of July. Positive effect of precipitation and low water pressure deficit (VPD) on growth was observed, while high VPD coincided with stem contraction. Results indicate the sensitivity of radial growth of European beech to water deficit and high atmospheric transpirational demand; therefore, future potential of cultivation of beech in Latvia depends on changes in moisture regime.
\end{abstract}

Key words: Fagus sylvatica L., climate change, radial growth, dendrometer, soil water potential.

Authors' addresses: 'Latvian State Forest Research Institute "Silava", 111 Rigas st., Salaspils, LV2169, Latvia; 'Society of Annas Tree School, “Annas koku skola”, Klīves, Babītes pag., Babītes nov., LV2107, Latvia; *e-mail: aris.jansons@silava.lv

\section{Introduction}

European beech (Fagus sylvatica L.) is one of the most important commercial tree species in Europe, its distribution range currently stretches from the southern part of the Scandinavian Peninsula in the North till Sicily in the South and from the Iberian Peninsula in the West till Western Ukraine in the East (Ellenberg, 1988, 1996; Fang \& DOI: $10.1515 /$ fsmu-2016-0010

(C) 2016 Estonian University of Life Sciences. All rights reserved
Lechowicz, 2006). Continentality, which can be characterized by high summer temperatures, summer droughts (Betsch et al., 2011) and late spring frosts (Augustaitis et al., 2015), is considered as one of the limiting factors of the distribution of European beech (Fang \& Lechowicz, 2006). Modelled occurrence and severity of drought occasions (Rasztovits et al., 2014) and decrease of probability of extreme cold events in the 
southern and northern parts of its distribution range, respectively, coincide with forecasted effects of global climate change (IPCC, 2014) and therefore with the natural distribution range of beech, which is expected to shift northwards (Hickler et al., 2012). Currently, in several forest stands (established at the end of $19^{\text {th }}$ century) in Western Latvia, beech have shown high level of acclimatization (Jansons et al., 2015), successful natural regeneration (Purina et al., 2016) and productivity similar to that of common tree species, like Norway spruce and silver birch (Dreimanis, 2006).

Detailed understanding of tree short term response to environmental conditions is important for predictions of tree growth in changing climate and subsequent development of forest management strategy. Data on short term responses based on stem diameter variation (SDV) can be conveniently gathered by means of dendrometry. Several studies (Ceschia et al., 2002; Knott, 2004; Charru et al., 2010; Šimpraga et al., 2011; Michelot et al., 2012) have used it to assess intra-annual growth of European beech. Fluctuations of stem diameter are result of contraction and expansion caused by irreversible increment of xylem, changes in tissue water storage, wood thermal properties and internal tensions of conducting elements (Daudet et al., 2005). Therefore, SDV can indicate the level of tissue hydration and potential drought stress (De Swaef et al., 2015).

As demonstrated by Steppe \& Lemeur (2004) and Michelot et al. (2012), growth of both juvenile and mature beech trees was drought sensitive. Sufficient water uptake ensures cell turgor pressure which is the main force providing cell expansion and division (Lockhart, 1967). Thereofre, minimized cell expansion in drought stressed trees is related to insuficient xylem hydration (Hsiao, 1973; Abe et al., 2003). Due to water deficit, newly-formed vessels are reduced in size (Sass \& Eckstein, 1995) which, in combination with reduction of xylem conductance (Barigah et al., 2013) hinders further water supply and hence assimilation.

So far such studies have not been carried out for European beech on the edge of its current distribution. Significant differences in water use have been found between dominant and suppressed beech trees, suggesting suppressed trees being under a higher drought stress risk beneath a closed canopy compared with dominant trees (Dalsgaard, 2008). Therefore, the aim of the study was to assess the intra-annual radial growth dynamics between dominant and suppressed European beech trees growing in northwest Latvia. We hypothesized that the intra-annual radial growth dynamics of beech in northwest Latvia is sensitive to water deficit.

\section{Material and Methods}

\section{Study area and study period}

The study area is located in north west Latvia $\left(57^{\circ} 14^{\prime} \mathrm{N}, 22^{\circ} 41^{\prime} \mathrm{E}\right)$ in the central part of Ziemelkursas upland which is situated in a hemiboreal mixed forest of the temperate climatic zone where annual air temperature and the sum of precipitation is $+6.3^{\circ} \mathrm{C}$ and $750 \mathrm{~mm}$, respectively (Latvian Environment, Geology and Meteorology Centre). Movement of North Atlantic air masses generally determines climatic conditions in Latvia; however, a gradient of small scale continentality in the territory of Latvia increases in direction from the coast in south west to inland in north east (Laivins š $\&$ Melecis, 2003; Draveniece, 2007). Therefore, regional differences in the duration of the vegetation period (in the western part of Latvia the vegetation period is 2 to 3 weeks longer than in the eastern part) are observed (Klavins \& Rodinov, 2010). According to the data from the closest meteorological observation station in Stende (about $20 \mathrm{~km}$ from the study site), both mean daily air temperature $\left(14.9^{\circ} \mathrm{C}\right)$ and sum of precipitation $(327$ $\mathrm{mm}$ ) of the studied period (May-August, 2014) exceeded 30-year means of the cor- 
responding period $\left(14.5^{\circ} \mathrm{C}\right.$ and $271 \mathrm{~mm}$, respectively).

Two nearby trees located $8 \mathrm{~m}$ from each other (DT-34.0 m high, diameter at breast height (DBH) $55 \mathrm{~cm}, 127$ years old and ST-12.6 m high, DBH $16 \mathrm{~cm}, 43$ years old) were sampled in a mixed Scots pine and European beech stand on well drained loamy soil in Hylocomiosa forest type. Sample trees were selected according to differences in dominance (DT formed the emergent layer of the stand while ST was located in the understory).

\section{Measurements of SDV, sap flow and weather parameters}

Monitoring of SDV was done at the breast height once per 10 minutes by automated band dendrometers DRL26C (EMS Brno, Czech Republic). Simultaneously, at the same height $(4 \mathrm{~m})$ of the trunk, xylem sap flow was measured every 10 minutes by applying the heat ratio method integrated in a SFM1 sap flow meter (ICT International, Australia). Probes of SFM1 have two measurement points with $15 \mathrm{~mm}$ spacing in between, and, to avoid the influence of ambient temperature on sap flow data, outer measurement point was placed in the depth of $5 \mathrm{~mm}$ below cambium layer within the sapwood (Burgess et al., 2001). Accordingly, inner measurement point was located in the sapwood in the depth of $20 \mathrm{~mm}$. Raw sap flow data were arranged by Sap Flow Tool software (ICT International, Australia) removing logging errors and applying correction factors (bark thickness, sapwood depth and tree size) for calculating the sap flow rate for the whole tree. Meteorological data used in study were obtained from a mobile weather station (Vantage Pro2, Davis Instruments, USA) located near the forest stand. Soil water potential was measured in the study site by using tensiometers (T8, UMS GmbH, Germany) and obtained data were stored in the DL6 logger (Delta-T Devices, UK).

\section{Data analysis}

Dendrometer data were analysed according to the methodology of stem cycle approach by Deslauriers et al. (2007) and Deslauriers et al. (2011). This method is based on division of daily pattern of stem shrinking/swelling cycles into different phases. Accordingly, phases of contraction (period between the daily maximum and next minimum), expansion (period between the end of contraction and next maximum) and increment (part of the expansion phase from the time the stem radius exceeds the previous maximum until the next maximum) were distinguished (Deslauriers et al., 2007) using DendrometeR package (van der Maaten et al., 2016) in $\mathrm{R}$ v.3.0.2. (R Core Team, 2016) software.

In order to characterize the relationship between sap flow rate and vapour pressure deficit (VPD), Gompertz function was fitted in analysis of nonlinear least squares:

$$
f(V P D)=\alpha^{-\beta-\gamma * V P D}
$$

where $\alpha=$ asymptote, $\beta=$ shape parameter, $\gamma=$ scale parameter. Coefficient of determination $\left(R^{2}\right)$ of the nonlinear model was obtained by the formula:

$$
R^{2}=\left(1-\sum r_{i}^{2}\right) /\left(\sum(y-\bar{x} y)^{2}\right),
$$

where $\sum r_{i}^{2}$ is residual sum of squares and $\sum(y-\bar{x} y)^{2}$ is total sum of squares. Statistical analysis was done in $\mathrm{R}$ v.3.0.2. (R Core Team, 2016) software.

\section{Results and Discussion}

The sum of precipitation and average air temperature of the studied period were 285 $\mathrm{mm}$ and $17.2^{\circ} \mathrm{C}$, respectively, but the mean value of VPD reached $1.2 \mathrm{kPa}$ (Figure 1C). Maximum air temperature was $33.4^{\circ} \mathrm{C}$, recorded in the beginning of August during a no rain period. Groundwater remained very low - between 19.48 and $19.41 \mathrm{~m}$ (Figure 1B), which, due to the geomorphological properties of the study site, is located in 

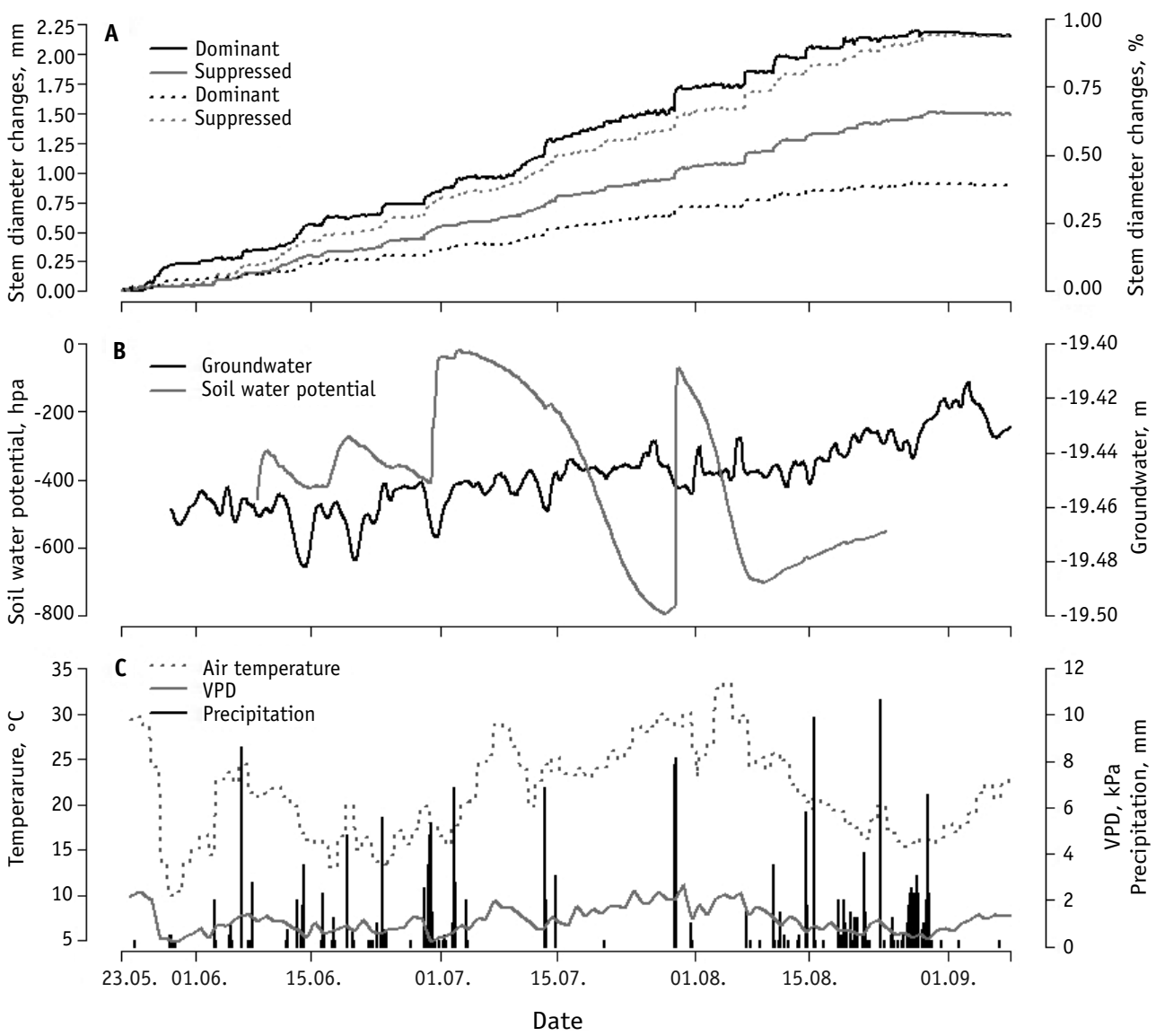

Figure 1. Seasonal course of changes in total (solid lines) and relative (dashed lines, secondary axis) radial increment (A), soil water potential and groundwater level (secondary axis) (B), and air temperature, vapour pressure deficit (VPD) and hourly sums of precipitation (secondary axis) (C).

the aquifer under a confining layer formed by fat clay. Therefore, capillary rise of water is excluded and soil moisture available for trees is supplied by precipitation only. Values of soil water potential fluctuated between drought conditions during the longest no rain periods with high VPD in the end of July/beginning of August and saturation right after intense rainfall along with decrease of VPD (Figure 1C).

Total radial increment for DT and ST tree was 2.2 and $1.5 \mathrm{~mm}$, respectively (Figure 1A). Nevertheless, ST had larger relative increment from the initial DBH compared to DT (0.93 and $0.38 \%$, respectively). At the end of dormancy, tissue rehydration and translocation of growth stimulants occur (Mäkinen et al., 2008), explaining the onset of fluctuations of stem diameter for both trees observed several weeks before the first record of increment phase. Following winter dehydration, restoration of sufficient xylem water content is one of preconditions for initiation of division of vascular cambium cells (Yamashita et al., 2006; Mäkinen et al., 2008); therefore, a rapid increase of stem diameter as it was observed for DT in the last decade of May (Figure 1) can be explained by reduced transpirational water loss due to a decrease of VPD (Steppe \& 

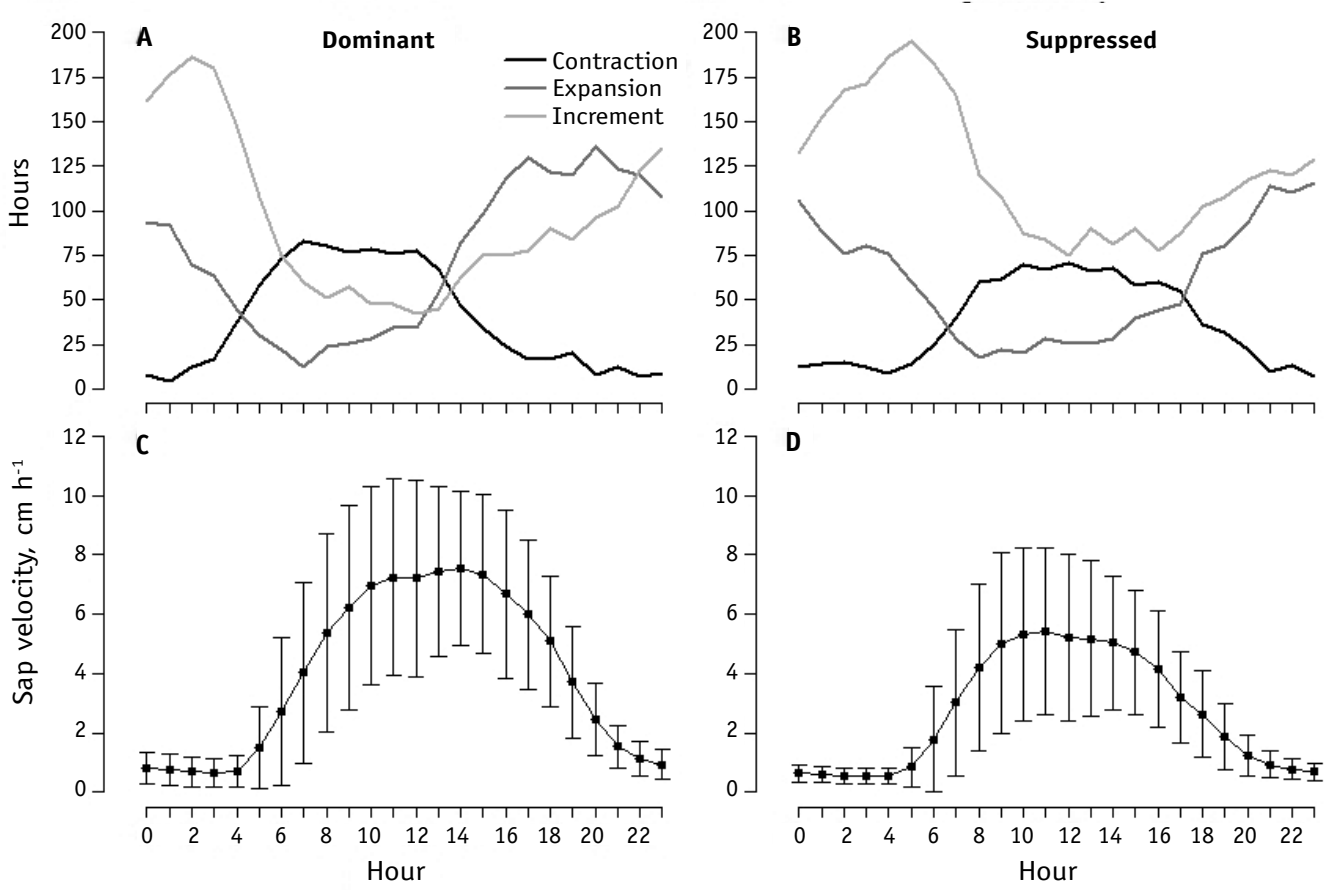

Figure 2. Hourly sums of duration of distinct phases of SDV (A;B) and mean hourly sap velocity (C; D).

Lemeur, 2004).

Notable increase of stem diameter for ST started 2 weeks after DT during the period with rain events (Figure $1 \mathrm{~A})$. Earlier growth onset for DT can be explained by higher root competitiveness of dominant trees which are very competitive, ensuring better water absorption (Le Goff \& Ottorini, 2001). During the observation period, cumulative changes of stem diameter formed a sawblade shaped curve with fluctuations caused by daily variations of wood hydration (Steppe \& Lemeur, 2004; Michelot et al., 2012). Pronounced leaps, corresponding to rain events and/or a decrease in VPD and air temperature, are distinguished as phases of increment. During such conditions, water absorbed from the soil is not being transpired completely but integrated into formation of xylem cells (Pallardy, 2008). Subsequently, for both trees the highest values of single increment phases were recorded just after rain events during periods when both air temperature and VPD decreased (Figure 1). Cumulative radial growth was completed in 98 and 101 days for DT and ST, respectively, which corresponds to results of the study from Slovenia by Čufar et al. (2008) showing that the average time of cambial activity for beech is 100 days. The timing of growth cessation generally is controlled by shortening of the photoperiod; however, age, vigour as well as environmental conditions influence the control of development of dormancy (Kozlowski \& Pallardy, 1997).

On the diurnal cycle, a period of the most intensive growth was observed in early morning, just before sunrise and subsequent start of daily sap flow; it was especially pronounced after stem rehydration following the rain events (Figure 2). Contraction of stems coincided with the increase of sap flow due to intensification of transpiration.

In the afternoon, sap flow decreased and expansion of stems due to restoration 


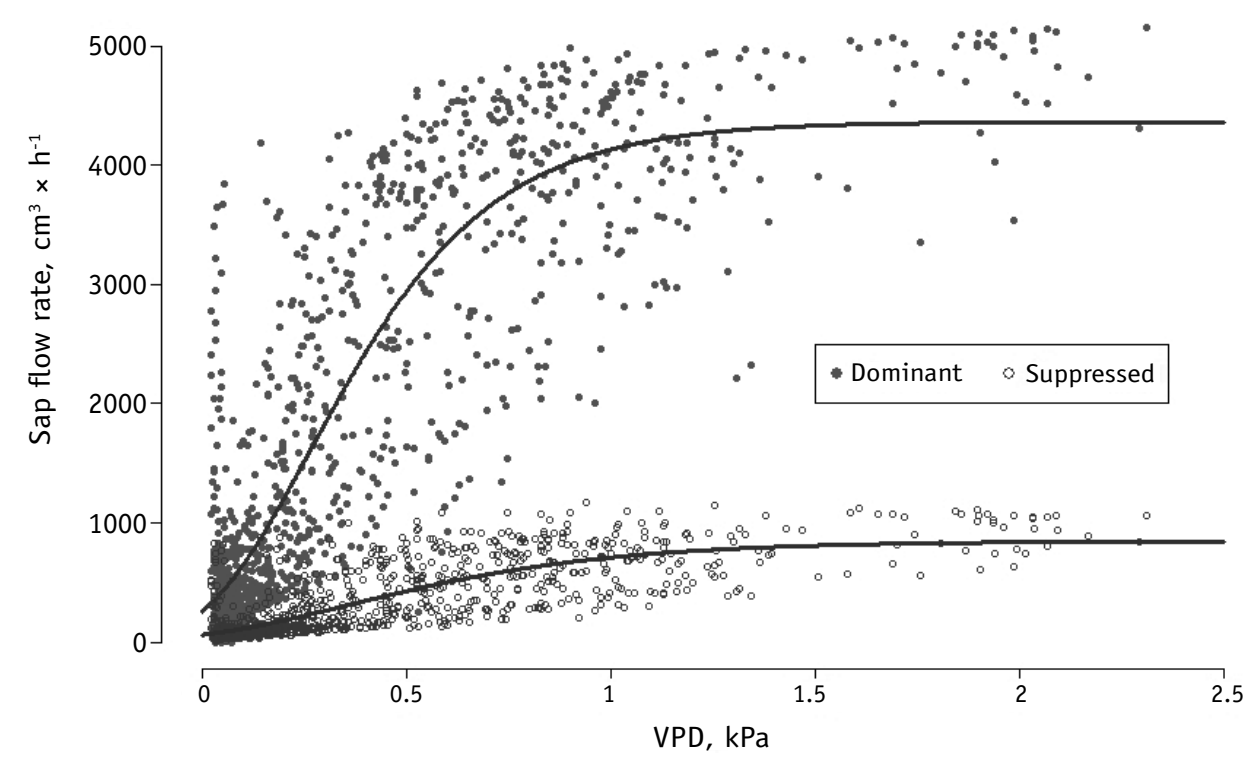

Figure 3. Relationship between sap flow rate and VPD in dominant (A) suppressed (B) tree.

of xylem water storage (Čermák et al., 2007) followed. Diurnal distribution of stem cycle phases between both trees was similar. However, during the diurnal cycle, total duration of increment phase for ST exceeded the duration of expansion and was longer compared with DT. Earlier onset of daily sap flow and following stem contraction for DT is caused by both higher root competitiveness and canopy exposure to direct solar radiation and wind compared with ST. In the understory layer, in the morning, air temperature increase and subsequent onset of transpiration is delayed in comparison with emergent layer of the stand (Granier, 1987). A diurnal peak of increment phase duration for ST was observed on average 3 hours later compared with DT, and subsequent start of contraction for ST was 1 hour later. Additionally, this phase lasted longer in the afternoon. Therefore, diurnal course of radial growth of ST showed less xylem water loss resulting in less sensitivity to weather conditions.

Since the success of tree growth is related to water availability (Pallardy, 2008), sap flow measurements can be used to trace tissue hydration and changes in vigour (Čermák et al., 2007). Čermák et al. (2007) showed that an increase of sap flow rate and depletion of internal water storage of the stem coincides. Comparing both sample trees, higher sap flow rates were observed for DT (up to $5000 \mathrm{~cm}^{3} \mathrm{ha}^{-1}$ ) than for ST (up to $1000 \mathrm{~cm}^{3} \mathrm{ha}^{-1}$ ). For both trees, high sap flow rates during very low VPD indicates rehydration during nights (Daley \& Phillips, 2006) or rainy/cloudy and cool days when formation of radial increment was observed (Figures 2,3). High sap flow rates during high VPD indicates water movement through xylem driven by transpiration during sunny, warm days coinciding with contraction of the stem or very low radial increment (Figure 1). An increase of VPD above $1.5 \mathrm{kPa}$ indicates upper limits of sap flow capacity for both trees. A high transpiration in combination with insufficient water supply causes stomata closure and cavitation leading to cessation of xylem sap flow (Jones, 1998; Tyree \& Sperry, 1989). Therefore, hydration of xylem tissue is hindered 
Table 1. Values of parameters $(\alpha, \beta$ and $\gamma)$ and performance of nonlinear model.

\begin{tabular}{cccc}
\hline Parameter \pm SD & Dominant & Suppressed & $p$-value \\
\hline$\alpha$ & $4364.03 \pm 76.82$ & $847.48 \pm 25.16$ & $<0.001$ \\
$\beta$ & $2.84 \pm 0.1$ & $2.64 \pm 0.1$ & $<0.001$ \\
$\gamma$ & $3.94 \pm 0.18$ & $2.69 \pm 0.16$ & $<0.001$ \\
\hline $\mathrm{R}^{2}$ & 0.76 & 0.66 &
\end{tabular}

(Zeppel et al., 2004). Turgor pressure is considered to be the main driving factor of vessel enlargement (Ray et al., 1972). Therefore, vessel growth is negatively affected by the water deficit (Sass \& Eckstein, 1995). Since larger vessels in diameter have higher water conducting capacity (Tyree \& Zimmermann, 2013), insufficient tissue hydration can have negative effect on growth during next vegetation period (Sass \& Eckstein, 1995).

Analysis of nonlinear least squares (Figure 3 and Table 1) resulted in a sigmoidal relationship between sap flow rate and VPD for both trees.

Differences in explained variances by the model for DT $\left(R^{2}=0.76\right)$ and ST $\left(R^{2}=\right.$ $0.66)$ and more rapid increase of sap flow rate (determined by differences in scale parameter $(\gamma)$ ) of DT at low values of VPD compared with ST, as already mentioned, can be explained by exposure of the canopy of DT to direct sunlight and wind favoring transpiration, thus providing large amounts of water for transpiration (Le Goff \& Ottorini, 2001).

\section{Conclusions}

Due to water deficit, formation of radial increment is very slow or completely interrupted until the restoration of stem water storage is completed facilitating the expansion of xylem cells. Thus, confirming our hypothesis that radial growth of European beech in northwest Latvia is sensitive to water deficit. Therefore, according to the predicted increase in mean annual air temperature, the future cultivation potential of beech in Latvia depends on the precipitation regime.
Acknowledgements. Study was carried out under the project: "Forest management risks: prognosis and minimization".

\section{References}

Abe, H., Nakai, T., Utsumi, Y., Kagawa, A. 2003. Temporal water deficit and wood formation in Cryptomeria japonica. - Tree Physiology, 23(12), 859-863.

Augustaitis, A., Kliučius, A., Marozas, V., Pilkauskas, M., Augustaitiene, I., Vitas, A., Staszewski, T., Jansons, A., Dreimanis, A. 2015. Sensitivity of European beech trees to unfavorable environmental factors on the edge and outside of their distribution range in northeastern Europe. - iForest, 9, 259-269.

Barigah, T.S., Charrier, O., Douris, M., Bonhomme, M., Herbette, S., Améglio, T., Fichot, R., Brignolas, F., Cochard, H. 2013. Water stress-induced xylem hydraulic failure is a causal factor of tree mortality in beech and poplar. - Annals of Botany, 10(23), 1-7.

Betsch, P., Bonal, D., Breda, N., Montpied, P., Peiffer, M., Tuzet, A., Granier, A. 2011. Drought effects on water relations in beech: the contribution of exchangeable water reservoirs. - Agricultural and Forest Meteorology, 151(5), 531-543.

Burgess, S.S., Adams, M.A., Turner, N.C., Beverly, C.R., Ong, C.K., Khan, A.A., Bleby, T.M. 2001. An improved heat pulse method to measure low and reverse rates of sap flow in woody plants. - Tree Physiology, 21(9), 589-598.

Čermák, J., Kučera, J., Bauerle, W.L., Phillips, N., Hinckley, T.M. 2007. Tree water storage and its diurnal dynamics related to sap flow and changes in stem volume in old-growth Douglas-fir trees. Tree Physiology, 27(2), 181-198.

Ceschia, É., Damesin, C., Lebaube, S., Pontailler, J.Y., Dufrêne, É. 2002. Spatial and seasonal variations in stem respiration of beech trees (Fagus sylvatica). Annals of Forest Science, 59(8), 801-812.

Charru, M., Seynave, I., Morneau, F., Bontemps, J. D. 2010. Recent changes in forest productivity: an analysis of national forest inventory data for common beech (Fagus sylvatica L.) in north-eastern France. - Forest Ecology and Management, 260(5), 864-874.

Čufar, K., Prislan, P., de Luis, M., Gričar, J. 2008. Treering variation, wood formation and phenology of 
beech (Fagus sylvatica) from a representative site in Slovenia, SE Central Europe. - Trees, 22(6), 749-758.

Daley, M.J., Phillips, N.G. 2006. Interspecific variation in nighttime transpiration and stomatal conductance in a mixed New England deciduous forest. Tree Physiology, 26, 411-419.

Dalsgaard, M.L. 2008. Transpiration and water budgets of European beech (Fagus sylvatica L.) dominated stands in relation to canopy structure. - Trees, 9(5), 247-252.

Daudet, F.A., Améglio, T., Cochard, H., Archilla, O., Lacointe, A. 2005. Experimental analysis of the role of water and carbon in tree stem diameter variations. - Journal of Experimental Botany, 56, 135-144.

De Swaef, T., De Schepper, V., Vandegehuchte, M.W., Steppe, K. 2015. Stem diameter variations as a versatile research tool in ecophysiology. - Tree Physiology, 35(10), 1047-1061.

Deslauriers, A., Rossi, S., Anfodillo, T. 2007. Dendrometer and intra-annual tree growth: What kind of information can be inferred? - Dendrochronologia, 25, 113-124.

Deslauriers, A., Rossi, S., Turcotte, A., Morin, H., Krause, C. 2011. A three-step procedure in SAS to analyze the time series from automatic dendrometers. - Dendrochronologia, 29, 151-161.

Draveniece, A. 2007. Oceanic and continental air masses over Latvia Riga. - Latvijas Veǵetācija, 14, 135 pp. (In Latvian with English abstract).

Dreimanis, A. 2006. Productivity of beech stands in Skede forest district. - Latvijas Lauksaimniecības Universitātes Raksti, 16, 94-100. (In Latvian with English abstract).

Ellenberg, H. 1988. Vegetation ecology of central Europe. Cambridge, Cambridge University Press. $735 \mathrm{pp}$.

Ellenberg, H. 1996. Vegetation of Central Europe with the Alps in ecological, dynamic and historical view. (Vegetation Mitteleuropas mit den Alpen in ökologischer, dynamischer und historischer Sicht). Stuttgart, Verlag Eugen Ulmer. 1095 pp. (In German).

Fang, J., Lechowicz, M.J. 2006. Climatic limits for the present distribution of beech (Fagus sylvatica L.) species in the world. - Journal of Biogeography, 33(10), 1804-1819.

Granier, A. 1987. Evaluation of transpiration in a Douglas-fir stand by means of sap flow measurements. Tree Physiology, 3(4), 309-320.

Hickler, T., Vohland, K., Feehan, J., Miller, P.A., Smith, B., Costa, L., Giesecke, T., Fronzek, S., Carter, T.R., Cramer, W., Kühn, I., Sykes, M.T. 2012. Projecting the future distribution of European potential natural vegetation zones with a generalized, tree species-based dynamic vegetation model. - Global Ecology and Biogeography, 21(1), 50-63.

Hsiao, T.C. 1973. Plant responses to water stress. - Annual Review of Plant Physiology, 24(1), 519-570.
IPCC. 2014. Climate Change 2014: Synthesis Report. Contribution of Working Groups I, II and III to the Fifth Assessment Report of the Intergovernmental Panel on Climate Change [WWW document]. - URL https://www.ipcc.ch/report/ar5/ syr/ [Accessed 3 September 2016].

Jansons, Ā., Matisons, R., Puriņa, L., Neimane, U., Jansons, J. 2015. Relationships between climatic variables and tree-ring width of European beech and European larch growing outside of their natural distribution area. - Silva Fennica, 49(1) article id 1255.

Jones, H.G. 1998. Stomatal control of photosynthesis and transpiration. - Journal of Experimental Botany, 49, 387-398.

Klavins, M., Rodinov, V. 2010. Influence of large-scale atmospheric circulation on climate in Latvia. - Boreal Environment Research, 15, 533-543.

Knott, R. 2004. Seasonal dynamics of the diameter increment of fir (Abies alba Mill.) and beech (Fagus sylvatica L.) in a mixed stand. - Journal of Forest Science, 50(4), 149-160.

Kozlowski, T.T., Pallardy, S.G. 1997. Physiological regulation of vegetative growth. - Kozlowski, T.T., Pallardy, S.G. (eds.). Growth control in woody plants. San Diego, Elsevier, 73-165.

Laiviņš, M., Melecis, V. 2003. Bio-geographical interpretation of climate data in Latvia: multidimensional analysis. - Acta Universitatis Latviensis, 654, 7-22.

Le Goff, N., Ottorini, J.M. 2001. Root biomass and biomass increment in a beech (Fagus sylvatica L.) stand in North-East France. - Annals of Forest Science, 58(1), 1-13.

Lockhart J.A. 1967. Physical nature of irreversible deformation of plant cells. - Plant Physiology, 42, 1545-1552.

van der Maaten, E., van der Maaten-Theunissen, M., Smiljanić, M., Rossi, S., Simard, S., Wilmking, M., Deslauriers A., Fontie, P., von Arxe, G. Bouriaud, O. 2016. dendrometeR: analyzing the pulse of trees in R. - Dendrochronologia, 40, 12-16.

Mäkinen, H., Seo, J.W., Nöjd, P., Schmitt, U., Jalkanen, R. 2008. Seasonal dynamics of wood formation: a comparison between pinning, microcoring and dendrometer measurements. - European Journal of Forest Research, 127(3), 235-245.

Michelot, A., Simard, S., Rathgeber, C., Dufrêne, E., Damesin, C. 2012. Comparing the intra-annual wood formation of three European species ( $\mathrm{Fa}$ gus sylvatica, Quercus petraea and Pinus sylvestris) as related to leaf phenology and non-structural carbohydrate dynamics. - Tree Physiology, 32(8), 1033-1045.

Pallardy, S.G. 2008. Physiology of Woody Plants (Third Edition). San Diego, Academic Press. 454 pp.

Puriņa, L., Neimane, U., Džeriņa, B., Jansons, Ā. 2016. European beech (Fagus sylvatica L.) regeneration affecting factors. - Mežzinātne, 27(60), 67-76. (In Latvian with English abstract). 
R Core Team. 2016. R: A language and environment for statistical computing. Vienna, R Foundation for Statistical Computing. 13 pp.

Rasztovits, E., Berki, I., Mátyás, C., Czimber, K., Pötzelsberger, E., Móricz, N. 2014. The incorporation of extreme drought events improves models for beech persistence at its distribution limit. - Annals of Forest Science, 71(2), 201-210.

Ray, P.M., Green, P.B., Cleland, R. 1972. Role of turgor in plant cell growth. - Nature, 239, 163-164

Sass, U., Eckstein, D. 1995. The variability of vessel size in beech (Fagus sylvatica L.) and its ecophysiological interpretation. - Trees, 9(5), 247-252.

Šimpraga, M., Verbeeck, H., Demarcke, M., Joó, É., Pokorska, O., Amelynck, C., Schoon, N., Dewulf, J., Van Langenhove, H., Heinesch, B., Aubinet, M., Laffineur, Q., Müller, J.-F., Steppe K. 2011. Clear link between drought stress, photosynthesis and biogenic volatile organic compounds in Fagus sylvatica L. - Atmospheric Environment, 45(30), 5254-5259.
Steppe, K., Lemeur, R. 2004. An experimental system for analysis of the dynamic sap-flow characteristics in young trees: results of a beech tree. - Functional Plant Biology, 31(1), 83-92.

Tyree, M.T., Sperry, J.S. 1989. Vulnerability of xylem to cavitation and embolism. - Annual Review of Plant Biology, 40(1), 19-36.

Tyree, M.T., Zimmermann, M.H. 2013. Xylem structure and the ascent of sap. Berlin, Springer Science \& Business Media. 146 pp.

Yamashita, K., Okada, N., Kamo, K. 2006. Application of the wire dendrometer for monitoring the radial growth of trees: a comparison with the conventional band dendrometer and the pinning method. - Mokuzai Gakkaishi, 52, 8-18. (In Japanese with English abstract and legends).

Zeppel, M.J., Murray, B.R., Barton, C., Eamus, D. 2004. Seasonal responses of xylem sap velocity to VPD and solar radiation during drought in a stand of native trees in temperate Australia. - Functional Plant Biology, 31(5), 461-470. 